UCRL -15382

P. 0. 8535303

Seismic and Geodetic Studies of the $\frac{1}{2}{ }_{\Sigma}$ Imperial Valley, California

David D. Jackson

University of California, Los Angeles

- Disclaimén

This book Wiscook was propas Neither the United States Goved, or assumes any legal liability or responsitility procoss disclosed, or:

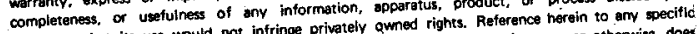

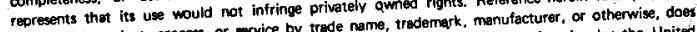

commercisl product, brocess, or service by trade name, trademark, manulact of fovoring by the Unitoc

not necesserily constitute or imply its endorsentions and opinions of suthors expressed

States Government of any agency thered. The vilus and ophior

OISTRIBUTION OF THIS DOCUMENT IS UNEIMUTED 


\section{DISCLAIMER}

This report was prepared as an account of work sponsored by an agency of the United States Government. Neither the United States Government nor any agency Thereof, nor any of their employees, makes any warranty, express or implied, or assumes any legal liability or responsibility for the accuracy, completeness, or usefulness of any information, apparatus, product, or process disclosed, or represents that its use would not infringe privately owned rights. Reference herein to any specific commercial product, process, or service by trade name, trademark, manufacturer, or otherwise does not necessarily constitute or imply its endorsement, recommendation, or favoring by the United States Government or any agency thereof. The views and opinions of authors expressed herein do not necessarily state or reflect those of the United States Government or any agency thereof. 


\section{DISCLAIMER}

Portions of this document may be illegible in electronic image products. Images are produced from the best available original document. 


\title{
SEISMIC AND GEODETIC STUDIES OF THE IMPERIAL VALLEY, CALIFORNIA
}

\author{
Final Technical Report \\ to \\ Lawrence LIvermore Laboratory \\ Purchase Order 8535303
}
by
David D. Jackson
Dept. Earth and Space Sciences.
UCLA

Los Angeles, California 90024

1 Nay 1981 


\section{SUIMARY}

The Imperfal Valiey exhibits perhaps the most active current tectonism In the United States; there are many earthquakes, and there is vigorous geodetic and geothermal activity. Patterns of gravitational and thermal anomalies, along with geodetic measurements, strike-slip faulting, and recent volcanism suggest that the continental crust may still be spreading (Elders et al., 1972). In recent years, the United States Geological Survey and

Caltech have added new seismic stations into a dense network in the Imperial Valley to study in detail the relationship between geothermal areas and rearthquakes, and to understand the tectonic processes taking place there. The National Geodetic Survey (NGS), Imperial County, the Imperial Irrigation District, and the U.S. Bureau of Reclamation have recently taken leveling measurements in the Imperial Valley to detect both geothermal and tectonic subsidence.

.....

The purposes of this study are (1) to examine crustal structure using recently available data on $P$-wave arrival times of local earthquakes, (2) to examine the leveling data for evidence of tectonic subsidence or uplift, and (3) to study correlations between seismicity, seismic velocity, geodetic motion, geothermal activity, and local geology to provide a more consistent: picture of the tectonics of the Imperial Valley. The primary conclusions of our study are as follows:

1) The region of thick sedimentary cover, trending NW-SE from the southern end of the Salton Sea, appears also to have a relatively thin crust with high P velocities.

2) A large fraction of the teleseismic travel time delays reported by Savino et al. (1977), and interpreted by them as resulting from crustal thinning, may instead result from overcorrection for surficial sediments or from velocity variations within the crust itself. 
3) One group of known geothermal resource areas, including Salton Sea (or Obsidian Buttes), Brawley, and East Mesa, lies on the axis of a zone of thin crust, and may be intimately related to the Brawley fault. The crust beneath these areas may be locally even thinner than elsewhere along the Imperial Valley trough, or the crust may have locally higher seismic velocities, or both. Neither local earthquake arrival times nor teleseismic arrival times are able to discriminate between these two hypotheses, but it is possible that the issue could be resolved by combining both sets of data.

4) A second group of known geothermal resource areas, including Heber, Dunes and Glamis, lies away from the projected trace of the Brawley fault. These areas are nearly aselsmic, and overlie crust with apparent seismic velocities only mildly higher than the regional average. These apparent velocity anomalies could be related to crustal thinning, but because of the very mild Bouguer gravity anomalies in these areas, it seems more likely that the velocity anomalies occur entirely within the crust.

5) Vextical crustal movements inferred from repeated leveling surveys exhibit locally erratic behavior, possibly the result of benchmark instabilities. Inferred tilt rates become tectonically plausible only if averaged over about a $10 \mathrm{~km}$ region. The center of the valley appears to be subsiding with respect to points on the west, with tilt rates of the order of $3 \times 10^{-7}$ radians per year. The tilt rate for the eastern side of the valley, between the Imperial and Sand Hills faults, appears to be less than the noise level in the data.

6) The leveling data are fit better by a model in which the vertical velocity varies continuously with position than they are by a block motion model with the same number of free parameters. This implies that if the 
geodetic motion is controlled by aseismic fault motion, this motion does not penetrate the surface sediments.

7) If the Imperial Valley is a region of active crustal spreading, as suggested by previous investigators, it is a rather strange one, with Iittle direct evidence of tension. Over the last decade, normal faulting has been rare, and the dominant horizontal crustal deformation has been N-S compression. It is of course possible that the last ten years have been anomalous. If not, the major geothermal areas may be explained by magmatism along strike-slip faults rather than by local crustal spreading. 


\author{
Appendix 1 \\ SEISMIC AND GEODETIC STUDIES OF THE \\ IMPERIAL VALLEY, CALIFORNIA
}
DAVID D. JACKSON
and

WOOK BAE LEE

\author{
Department of Earth and Space Sciences \\ University of California, Los Angeles \\ Los Angeles, California 90024
}

\title{
15. April 81
}




\section{SUMMARY}

The Imperial Valley exhibits perhaps the most active current tectonism In the United States; there are many earthquakes, and there is vigorous geodetic and geothermal activity. Patterns of gravitational and thermal anomalies, along with geodetic measurements, strike-slip faulting, and recent volcanism suggest that the continental crust may still be spreading (Elders et al., 1972). In recent years, the United States Geological Survey and Caltech have added new selsmic stations into a dense network in the Imperial Valley to study in detall the relationship between geothermal areas and earthquakes, and to understand the tectonic processes taking place there. The National Geodetic Survey (NGS), Imperial County, the Imperial Irrigation District, and the U.S. Bureau of Reclamation have recently taken leveling measurements in the Imperial Valley to detect both geothermal and tectonic subsidence.

The purposes of this study are (1) to examine crustal structure using recently available data on $\mathrm{P}$-wave arrival times of local earthquakes, (2) to examine the leveling data for evidence of tectonic subsidence or uplift, and (3) to study correlations between seismicity, seismic velocity, geodetic motion, geothermal activity, and local geology to provide a more consistent plcture of the tectonics of the Imperial Valley. The primary conclusions of our study are as follows:

1) The region of thick sedimentary cover, trending NN-SE from the southern end of the Salton Sea, appears also to have a relatively thin crust with high $P$ velocities.

2) A large fraction of the teleseismic travel time delays reported by Savino et al. (1977), and interpreted by them as resulting from crustal thinning, may instead result from overcorrection for surficial sediments or from velocity variations within the crust itself. 
3) One group of known geothermal resource areas, including Salton Sea (or Obsidian Buttes), Brawley, and East Mesa, lies on the axis of a zone of thin crust, and may be intimately related to the Brawley fault. The crust beneath these areas may be locally even thinner than elsewhere along the Imperial Valley trough, or the crust may have locally higher seismic velocities, or both. Neither local earthquake arrival times nor teleseismic arrival times are able to discriminate between these two hypotheses, but it is possible that the issue could be resolved by combining both sets of data.

4) A second group of known geothermal resource areas, Including Heber, Dunes and Glamis, lies away from the projected trace of the Brawley fault. These areas are nearly aseismic, and overlie crust with apparent seismic velocities only mildiy higher than the regional average. These apparent velocity anomalies could be related to crustal thinning, but because of the very mild Bouguer gravity anomalies in these areas, it seems more 1ikely that the velocity anomalies occur entirely within the crust.

5) Vertical crustal movements inferred from repeated leveling surveys exhibit locally erratic behavior, possibly the result of benchmark instabilities. Inferred tilt rates become tectonically plausible only if averaged over about a $10 \mathrm{~km}$ region. The center of the valley appears to be subsiding with respect to points on the west, with tilt rates of the order of $3 \times 10^{-7}$ radians per year. The tilt rate for the eastern side of the valley, between the Imperial and Sand Hills faults, appears to be less than the noise level in the data.

6) The leveling data are fit better by a model in which the vertical velocity varies continuously with position than they are by a block motion model with the same number of free parameters. This implies that if the 
geodetic motion is controlled by aseismic fault motion, this motion does not penetrate the surface sediments.

7) If the Imperial Valley is a region of active crustal spreading, as suggested by previous investigators, it is a rather strange one, with little direct evidence of tension. Over the last decade, normal faulting has been rare, and the dominant horizontal crustal deformation has been N-S compression. It is of course possible that the last ten years have been anomalous. If not, the major geothermal areas may be explained by magmatism along strike-slip faults rather than by local crustal spreading. 
2. GEOLOGY, GEOPHYSICS, AND TECTONIC SETTING

The Imperial Valley, the landward extension of the Gulf of California, is a broad, structural trough partly filled with deltaic silts, sands and gravels of late Tertlary age, and by thick Quaternary alluvium and lake sediments. It is a complex rift valley bordered by mountains consisting of Mesozoic and older granitic basement rocks and Tertiary volcanic rocks. The sediments were probably deposited by the Colorado River during the lastfew million years. Major faults in the region include the Imperial fault, Sand Hills fault, San Jacinto fault, Laguna Salada fault and the Brawley fault (Figure 1). Several young volcanoes occur at Cerro Prieto, $30 \mathrm{~km}$ south of Mexicali, and also at the southern end of Salton Sea as well as in the Gulf. The thick sediments of the Imperial Valley contain geothermal brines near the Known Geothermal Reservoir Areas (KGRA), which are Indicated in Figure 1 by capital letters as follows: B=Brawley; D=Dunes; EM=East Mesa; G=Glamis; H=Heber; SS=Salton Sea; C=Cerro Prieto.

With the exception of the rhyolite volcanics at obsidian Buttes and the dacite volcanics further south at Cerro Prieto, Mexico, the basin is well covered with recent sediments. According to Elders et al. (1972) these sediments are as thick as six or seven $\mathrm{km}$ along the axis of the valley. In spite of the low density sediments, there is a broad 20 mgal maximum in Bouguer gravity anomaly along the axis of the valley; allowing for the effect of the sediments, it appears that there is a 70 mgal gravity high resulting from a regional mass excess (Elders et al., 1972; Savino et al., 1977). The width of this feature is approximately $1^{\circ}$ longitude. The extent to which the basin is isostatically compensated has not been properly resolved. Elders et al. state that the basin is isostatically compensated south of the Salton Sea, while McGinnis et al. (1979) show a significant 
negative free air gravity anomaly for the Imperial Valley region when data are averaged over $15^{\prime}$ quadrangles or larger areas.

Magnetic data for the Imperial Valley are as dull as the topography. There is not much to discuss except in those few places where volcanic rocks are exposed at the surface.

Heat flow results are a bit more interesting. The average heat flow In the region is roughly twice the national average (Lachenbruch and Sass, 1975) and locally, the heat flow reaches much higher values. For example, the heat flow reaches $7.1 \mathrm{cal} / \mathrm{cm}^{2} \mathrm{sec}\left(370 \mathrm{~mW} / \mathrm{m}^{2}\right)$ near the Obsidian Buttes at the southeastern tip of the Salton Sea. In general, regions of high heat flow are also regions of mildly positive Bouguer gravity anomalies.

Savino et al. (1977) used a combination of teleseismic P-wave travel times and Bouguer gravity anomaly data to infer crustal structure in the Imperial Valley, assuming a Iinear relationship between density and P-wave velocity. After correcting for the effects of low density, low velocity sediments, they found relatively early P-wave arrivals at stations along the axis of the valley, with especially early arrivals near the known geothermal areas. Similarly, the Bouguer gravity anomaly, after corrections for the sediments, was high along the axis of the valley, and was locally high near the known geothermal areas. The cause of these anomalies could be some combination of (a) mantle upwelling; (b) densification of crustal rocks, possibly resulting from cementation of the crustal rocks by geothermal. fluids, and (c) overcorrection for the sediments. These hypotheses all involve density and velocity anomalies, which would occur at the base of the crust according to hypothesis (a), within the crystalline crust according to hypothesis (b), or withing the sediments according to (c). Tectonically, these hypotheses would have quite different implications, since hypothesis (a) would directly involve crustal thinning and therefore horizontal tensional 
stresses, while (b) or (c) would not require such tension. Thus, it is Important to resolve the depth at which the velocity and density anomalies occur. Unfortunately, teleseismic $P$ waves travel at nearly vertical incidence through the crust, and therefore provide little depth resolution. Gravity data may help to improve the depth resolution, if gravity and density variations are proportional to one another, but the degree of improvement is probably slight. Savino et al. accept hypothesis (a), equating the velocity and density variations with crustal thickness variations, without testing the competing hypotheses against the data.

Seismicity and earthquake focal mechanisms have been studied by Hill et al. (1975), who observed an earthquake swarm in 1973. They found that the seismicity was characterized by a narrow zone of right lateral events extending between the Brawley and the Imperial faults, and a broader zone of right lateral activity along the San Jacinto fault. The Sand Hills fault, an extension of the San Andreas-Banning-Mission Creek faults, was as quiet as a churchmouse. There was seismic activity at the Salton Sea and Brawley geothermal fields which lie on the Brawley fault, and at the Heber field, which lies near the extension of the San Jacinto fault, but the Glamis, Dunes and East Mesa flelds were all pretty quiet. There was no evidence suggesting normal faulting in any of the seismic source mechanisms.

Johnson and Hadley (1976) made an exhaustive study of a swarm near Brawley that occurred in January of 1975. Using a master event location procedure, they detected three lineations of selsmiclty. The major Iineation, which they referred to as the Brawley fault, intersects the Imperial fault, bears $N 8^{\circ} \mathrm{W}$ for most of its length, bending westward to about $N 45^{\circ} \mathrm{W}$ near the Salton Sea. Most of the events occurred on the central section of the fault 
and were apparently right lateral events. Note that Hill et al. disagree with Johnson and Hadley both in the definitions of the Brawley fault (Hill. et al. show it NW-SE as on Figure 1) and on the major compression axis for events between the Brawley and Imperial faults. Hill et al. estimate N-S compression while Johnson and Hadley apparently estimate maximum compresision at $N 37^{\circ} \mathrm{E}\left(45^{\circ}\right.$ east of $\left.\mathrm{N} 3^{\circ} \mathrm{W}\right)$. The other two lineations found by Johnson and Hadley trended NE-SW, and the events thereon were a mixed bag of thrust, normal, and left lateral events.

Gilpin and Lee (1978) monitored micro-earthquake activity at the Salton Sea geothermal field for eight weeks in 1975, using 5 portable and two permanent stations. They found that the Brawley fault is apparently split Into a family of at least two en echelon fault segments trending $\mathrm{N} 50^{\circ} \mathrm{W}$. Many of the epicenters occurred between two segments of the fault separated by about $4 \mathrm{~km}$. For one poorly recorded swarm, there was evidence of normal faulting on either of two planes striking $N 65^{\circ} \mathrm{E}$. However, there were only three events in the swarm that produced clear first motions, and the station distribution was rather poor for determining focal mechanisms, so this result must be regarded with caution. A second swarm Indicated either right lateral faulting on a fault trending $N 30^{\circ} \mathrm{E}$, or left lateral faulting trending $\mathrm{N} 60^{\circ} \mathrm{W}$

Geodimeter studies within the Imperial Valley suggest that since 1972 it has, like most of Southern Calffornia, been subjected to relatively unfform north-south compression at the rate of a few parts in $10^{7}$ per year (Savage et a1., 1979). This uniaxial compression could be interpreted as a superposition of right lateral shear straining parallel to the San Andreas fault system and uniform horizontal compression. Triangulation results over a much longer period of time (Thatcher, 1979) suggest right lateral shear 
straining. Because the triangulation data are not sensitive to uniform compression, there is no discrepancy between the geodimeter and triangulation results.

A commonly accepted view of the Salton trough is that it is a rift valley formed by spreading away from the landward extension of the East. Pacific Rise. This view is set forth in detail by Elders et al. (1972), who suggest that the Salton Sea, Brawley and Cerro Prieto geothermal areas are all short sections of spreading center offset by transform faults. According to that interpretation, the entire Salton trough is under NW-SE tension, and the extensive sediments filling the valley have resulted from crustal thinning in response to this tension. After correction for the estimated effect of the low density sediment, the regional Bouguer gravity anomaly shows a high of about $70 \mathrm{mgal}$. The following hypotheses could account for the gravity high:

(a) relative thinning of the crust at the bottom (upward migration of the crust mantle boundary) by up to $8 \mathrm{~km}$;

(b) a lateral density variation averaging about $0.4 \mathrm{~g} / \mathrm{cm}^{3}$ over the thickness of the crust; or

(c) overcorrection for the effects of the sediments.

The first two hypotheses were suggested by Elders et al. (1972), while the third is our own.

A significant problem with the interpretation of Elders et al. Is the Implication of NW-SE tension. Such tension could be viewed as the superposition of uniform horizontal tension upon efther right lateral shear straining on a N-S axis, or left lateral shear straining on an E-W axis. Neither the earthquake focal mechanisms nor the observed geodetic motions support this requirement. 
Hi11 (1977) and Weaver and H111 (1978) have suggested a model that would help to explain most of the data. According to this model, the greatest compressive stress, on a regional scale, is oriented $\mathrm{N}-\mathrm{S}$, and the least compressive stress is oriented $E-W$. When the difference between these two stresses is great enough, N-S oriented dikes may be formed. The tips of these dikes would then be joined by a conjugate system of NW-SE right lateral faults and NE-SW left lateral faults. Where two NW-SE right lateral faults are offset in a dextral sense, as are the Imperial and Brawley faults, regional block motion requires a net outflux of material from the region between the two faults. In this situation, the dikes may Iine up in one or more $\mathbb{N}-S$ trending groups between the right lateral faults, forming a "leaky transform fault". The model predicts only local tension (resulting from strength and rigidity variations in the crust). This local tension may or may not result in earthquakes, depending on the tensional strength of the rocks near the dikes, but should result in crustal thinning and surface subsidence. Most of the earthquakes should be on the strike-slip faults running between the tip of the dikes. This model is in good agreement with the observed N-S regional compression, the strike-slip focal mechanisms observed by Hill et al. (1975), and the general N-S alignment of epicenters between the Imperial and Brawley faults. It does not explain the focal mechanisms observed by Johnson and Hadley for earthquakes at the South end of this zone (right lateral slip on $N 8^{\circ} \mathrm{W}$ fault) and with the reported thrust earthquakes on the splay faults, but you can't expect everything, can you? 


\section{ARRIVAL TIMES FROM LOCAL EARTHQUAKES}

Sefsmic arrival times are affected by the hypocentral parameters, and the seismic slowness along the path between source and receiver. In general, neither the hypocentral parameters, nor the slowness, nor the path, is known in advance. In order to estimate these quantities, it is convenient to formulate a simple slowness model, locate the earthquakes, and then to perturb the slowness structure so as to reduce the residuals. In general, perturbing the velocity structure also perturbs the ray path, but our numerical studies have shown that the travel time may be calculated to high accuracy by integrating the perturbed slowness along the original path. Simple models for slowness perturbations include the "station delay" model, in which the velocity perturbations are assumed to be localized near enough to the receivers that the delay is independent of the path from the source, and the "block model", in which travel time variations are proportional to the distance traveled in eàch of several blocks of constant slowness. Roughly speaking, the station delay model focuses on shallow features, and the block model concentrates on deeper features. In the typical case, either model will go a long way toward reducing residuals to about the nolse level in the data, implying that the data have poor depth resolution. We found this to be true of the Imperial Valley as well: we found average residuals at some stations to vary by as much a 1 s., but we could not tell whether the variations are caused within the upper crust, the lower crust, or somewhere in between.

Data errors include reading errors, blunders, errors in estimating the appropriate velocities and station corrections, and the effects of velocity variations not included in the perturbation scheme. We assume that reading errors and blunders are roughly independent of station but may be related to 
epicentral distance. Errors in estimating station correction will contribute an additive term to the variance at each station and will differ from station to station. The effects of random velocity variations have been studied by Chernov (1960), who developed a model for the propagation of electromagnetic radiation in randomly heterogeneous medium. His result, that the variance of the phase arrival time increases linearly with path length, should be applicable to selsmic waves if the velocity and path variations are small.

Our model is then,

$$
t_{1 j}=t_{o j}+f\left(\Delta_{i j}, z_{j}\right)+\Delta t_{i}+\sum_{k} d_{i j k} s_{k}+e_{1 j}
$$

where:

1 is a station index

$f$ is an event index

$t_{1 j}$ is the observed arrival time for event $j$ at station 1

$t_{o j}$ is the origin time of event $j$

$\Delta_{1 j}$ Is the epicentral distance between station $i$ and event $j$

$z_{\mathfrak{j}}$ is the hypocentral depth of event $\mathfrak{j}$

$f$ is the theoretical travel time in a layered half space

$\Delta t_{i}$ is the station correction at station 1

$d_{1 j k}$ is the path length within geographical region $k$, for a straight line between event $\mathcal{j}$ and station $i$

$S_{k}$ is the slowness perturbation in region $k$

$e_{\text {if }}$ is a random error

The data errors $e_{i j}$ are assumed to have zero mean and variance of the form $\operatorname{var}\left(e_{1 j}\right)=\sigma_{1}^{2}+\alpha \Delta_{i j}$

where $\sigma_{i}^{2}$ is the station variance and $\alpha$ is a parameter to be determined from the data. The first term includes reading errors and blunders as well as 
uncertainties in the station correction (i.e., the effects of random velocity variations beneath the station). The second term includes the Chernov effect plus a contribution from the increased likelihood of phase misidentification at large epicentral distances. We have developed a procedure for estimating the parameters $\Delta t_{i}, s_{k}, \sigma_{i}^{2}$, and $\alpha$, as well as the hypocentral parameters of all events used, from a given set of arrival time data. First, preliminary event locations are estlmated using HYPO-71 (Lee and Lahr, 1975). Second, the arrival time residuals are used to estimate $s_{k}, \sigma_{i}^{2}$ and $\alpha_{\text {. Estimation of }}$ $S_{k}$ is a straightforward linear inverse problem, given $\sigma_{i}^{2}$ and $\alpha$. Estimation of $\sigma_{1}^{2}$ and $\alpha$ are done by the maximum likelihood method. Third, arrival times are corrected for velocity variation $\left(s_{k}\right)$ and earthquakes are relocated using modified estimates of $\sigma_{i}^{2}$ and $\alpha$. The second and third steps are then Iterated until none of the unknown parameters changes substantially between iterations. 
4. ARRIVAL TIMES FOR IMPERIAL VALLEY

The procedure described above has been applied to the Imperial Valley catalog of June 1975 - September 1977. The data have been edited to eliminate some blunders and duplicate readings. The edited version of the catalog Includes 1608 events during the period. The recording stations we used Include 50 stations (listed in Table 1). The events in the edited catalog were located by HYPO-71 (Lee and Lahr, 1975) using initial velocity model of layered half space (Table 2) based on a selsmic refraction study of the Imperial Valley by Biehler et al. (1964). Grade D events which have poor solution quality or RMS residual greater than 0.5 seconds, and epicentral error greater than $5 \mathrm{~km}$, have not been used.

Because of financial limitations, we were not able to estimate simultaneously all of the unknown parameters in equations (1) and (2). Instead, we made some simplifying assumptions, and calculated different estimates that place useful limits on the values of the parameters. In one model, referred to as model A, we assumed that all of the lateral variations in travel time are caused by near surface delays. We thus constrained the lateral slowness varlations $S_{k}$ to be zero for all regions and estimated the remaining parameters by iteration. In model $\mathrm{B}$, we assumed that all of the travel time delays are caused by regional slowness variations. We constrained the local station corrections $\Delta t_{0 i}$ to be zero for all stations, and estimated the remaining parameters by iteration. In model $c$, we corrected the travel time data by subtracting the station corrections of model $A$, then estimated the slowness perturbations from the corrected residuals.

The true station corrections should be bracketed by models $A$ and $B$. Model A almost certainly overestimates the variations in station delay, because it ascribes all travel time variations to the station delays. 
Model B certainly underestimates the variations in station delay, because it assumes they are all zero. Simflarly, the reglonal slowness variations will be bracketed by models A (where they are assumed to be zero) and B (where they are blamed for all travel time variations). Model $\mathrm{C}$ uses the same (overestimated) station corrections as model $\mathrm{A}$, so it will also underestimate the velocity variations. For this reason we are confident that the true station corrections and regional velocity variations lie between those of model $B$ and model $C$.

Our next step would have been to relocate the earthquakes using the two dimensional velocity model and to revise the station corrections, but we could not afford the computational costs. Trial studies indicated that neither the hypocentral locations nor the station corrections would have changed by more than a small fraction of their claimed uncertainty. 
5. ESTIMATED STATION DELAYS (MODEL A)

Assuming a laterally homogeneous velocity model as shown in Table 2, we estimated hypocentral locations and station corrections $\Delta t_{1}$ for all stations. Individual station corrections are shown in Table 1 and contoured in Figure 2. All corrections are computed relative to the mean, and negative corrections indicate stations that show early arrivals (negative residuals). The outstanding feature on Figure 2 is the wide band of relatively late arrivals stretching from the southeast end of the Salton Sea and continuing south and slightly east into Baja California. The band follows the axis of the valley and correlates well with the regions of thickest sediments.

The latest arrivals occur just between the Brawley and Salton Sea geothermal fields, and just north of the Heber field. There are also late arrivals at a station just south of the East Mesa field. The Glamis field does not show any striking anomaly, but 1 t is not well covered with seismic stations either. Fast arrivals occur on the flanks of the valley where crystalline rocks are exposed. 


\section{LATERAL VELOCITY VARIATIONS (MODEL B)}

We next inverted the data to obtain lateral variations in seismic velocity, constraining the station corrections to zero. We let the slowness vary from the original model only in the layer from 6 to $20 \mathrm{~km}$ depth. We divided the region defined by $32^{\circ} 30^{\prime} \leq$ latitude $\leq 33^{\circ} 30^{\prime}$ and $-116^{\circ} \leq$ longitude $\leq 115^{\circ}$ into a grid of 64 blocks, each having dimensions $7.5^{\prime} \times 7.5^{\prime}$. We assumed a uniform slowness perturbation within each block and solved for the value of the perturbations using a weighted least squares method. We then inverted the slowness to obtain velocity, and contoured the results for ease of presentation. The results are shown in Figure 3. High velocity regions are well related to geothermal fields at Salton Sea, Brawley, Glammis, Dunes, and East Mesa. The Heber field is in a region of poorly resolved velocity. The high velocities could indicate elther crustal thinning, intrusion of high velocity volcanic material or extensive hydrothermal alteration.

The contrast between Figures 2 and 3 is rather striking; three quadrangles southeast of Salton Sea that show late arrivals in Figure 2 show high velocities in Figure 3. It is likely that these areas have a thin, high velocity crust, overlain by thick slow sediments. Rays traveling to stations within these zones must penetrate the sediments, whereas rays that are just passing through may duck under. The areas of thin crust deduced by Savino et a1. are near, but not coincident, with areas that we find to have high velocities with the crust. 


\section{COMBINED INVERSION FOR STATION CORRECTIONS AND LATERAL VELOCITY VARIATIONS (MODEL C)}

In an attempt to assess the depth resolution of the local earthquake data set, we corrected the observed arrival times for the estimated station delays (given in Table 1) and again estimated the regional slowness variations. We then converted slowness estimates to velocity estimates for ease of Interpretation. A contour map of estimated velocity variations is shown in Figure 4. The map shows more geographical structure, and much smaller velocity variations, than those shown in Figure 3. There is still a general NW-SE trend to the velocity map. However, where Figure 3 showed a broad zone of high velocities trending SE from the Salton Sea, Figure 4 suggests a linear zone of high velocities to the NE of and adjacent to a linear zone of low velocities, both zones trending parallel to the San Andreas Fault system. In Figure 4, there is only a suggestive correlation between seismic velocity and known geothermal activity. The Salton Sea and East Mesa fields lie on the above-mentioned high velocity trend, and the Brawley field lies just off of it. Glamis straddles a mildly fast region, but this may be an artifact caused by its proximity to the chocolate Mountains. Heber and Dunes both lie in very neutral territory.

We tend to favor the picture given in Figure 4 (the simultaneous Inversion) over that of Figure 3, partly for aesthetic reasons: the estimated velocity variations are not so extreme, and the NW-SE trend is more consistent with the tectonic structure than the reverse trend of Figure 3. Furthermore, the station delays that accompany Figure 4 are more consistent with sediment thickness variations than are the null values used in deriving Figure 3. 
The local earthquake data by themselves cannot distinguish between models $B$ and $C$; both fit the data reasonably we11. However, models $B$ and C together provide meaningful limits of the structure of the Imperial Valley. In model $\mathrm{B}$, the variations in observed arrival times are ascribed entirely to velocity variations in the crystalline part of the crust. In model $c$ the variations are largely ascribed to the station corrections, assumed to be related to near surface velocity variations. Our experience with synthetic data indicate that our procedure will tend to underestimate velocity variations if the station corrections are estimated first, as in model $c$. We are thus confident that the true station corrections lie somewhere between zero (as assumed in model B) and the estimated values in Table 1; similarly, the velocity variations lie somewhere between those shown in Figures 3 and 4 . 
8. SIMULTANEOUS USE OF LOCAL AND TELESEISMIC DATA TO IMPROVE DEPTH RESOLUTION

While neither the local earthquake data, nor the teleseismic data provide much depth resolution, consideration of both data sets together offers some improvement. Ideally, we would like to invert both data sets simultaneously, but this would be a falrly awesome undertaking and we haven't done it so far. However, a comparison of the results of the separate inversions can help to resolve the issue of where the most significant velocity variations are taking place.

The teleseismic results of Savino et al. (1977) are compared with our results for local earthquakes in Table 3. Column 1 shows the observed teleseismic delay at each of 16 stations, averaged over all azimuths. The next column shows the estimated delay for near surface sediments based on seismic refraction data by Biehler et al. 1964. The third column shows the residual delays, assumed by Savino et al. to be caused by variations in crustal thickness. Column 4 shows the estimated delays for vertically incident $\mathrm{P}$ waves calculated from model $\mathrm{C}$. These delays include contributions from the sediments (column 5) and from velocity variations within the crystalline crust (column 6 ). Note that all delays in Table 3 are calculated with respect to the mean of the first ten stations, which are all within the Salton trough. The remaining six stations are not included in the mean because they are on the margins of the valley, and the estimates of their station corrections are not as accurate as for the interior stations. Clearly there are velocity variations in the near surface materials. Savino et al. have estimated the resulting delays from published refraction results, and have corrected their teleseismic data for them. We have independently estimated station delays from local earthquake data. If the 
residual teleseismic delays were caused by crustal thickness variations or upper mantle velocity variations, as assumed by Savino et al., then presumably our estimated station delays should be nearly equal to theirs. This is because our data are for rays that stay entirely within the crust, and by hypothesis the crustal velocity is constant except near the surface. The station delays assumed by Savino et al. are plotted against ours in Figure 5a. While the two data sets are correlated, the two estimates of station delays are far from equal. The difference values (teleseismic minus local) have an estimated standard deviation of $.16 \mathrm{~s}$, averaged over the 10 interior stations, with a range from $-.19 s$ to $+2.5 s$.

Significantly better agreement is shown in Figure $5 \mathrm{~b}$, where the total observed teleseismic delay. (with no sediment correction) is plotted against our estimated station delays. For the ten interlor stations, the differences have a standard deviation of $.09 \mathrm{~s}$, with a range from $-.09 \mathrm{~s}$ to $.18 \mathrm{~s}$. This 
agreement suggests that the teleseismic delays observed by Savino et al. are caused by variations in sediment thickness rather than by variations in crustal thickness.

Figure 6a shows a plot of the assumed station delay for the teleseismic data as a function of the total crustal delay estimated from our model $C$. The total crustal delay for nodel $C$ was estimated by adding to the station delay the time required to travel thru $14 \mathrm{~km}$ of crystalline crust having the velocity estimated in model $C$. Agreement in Figure 6 a would suggest that the station correction used by Savino et al. includes a substantial contribution from the crystalline crust. However, such agreement is not achieved; the differences for the first ten station have an estimated standard deviation of $.17 \mathrm{~s}$, , with a range from $-.20 \mathrm{~s}$ to $.24 \mathrm{~s}$.

Figure $6 \mathrm{~b}$ suggests that the observed teleseismic delays can be we1l explained by velocity variations entirely within a cxust as described by model.c. The differences between the teleseismic observations and the predictions from model $\mathrm{C}$ have an estimated standard deviation of $0.08 \mathrm{~s}$, with a range from $-.12 \mathrm{~s}$ to $.13 \mathrm{~s}$, for the 10 interior stations - Stations on the margin of the valley generally depart from the relationship observed for interior stations. We think that this is caused by poor estimates of the station corrections for marginal stations in our model. The marginal stations generally receive early arrivals that have travelled at high speed through the mountainous regions peripheral to the Imperial valley. Because the crustal velocities in these areas are not properly estimated in our model, the early arrivals result in artificially negative station correction estimates.

The data that were used in constructing model $\mathrm{C}$ were for local earthquakes 
only, and few rays if any ever escaped the crust. Thus the good agreement shown in Figure 6b implies that the teleselsmic delays observed by Savino et al. were accumulated almost entirely within the crust, above about $20 \mathrm{~km}$ depth. This finding conflicts with their original interpretation that the relative time delays were caused by variations in depth to the mantle. We do see in Figure $6 \mathrm{~b}$ a suggestion that the teleseismic arrivals are relatively early at stations on the axis of the valley (where the estimated crustal delay is positive) and late where the crustal delay is negative. This suggests a small amount of crustal thinning, but not as much as suggested by Savino et al. The teleseismic data, as corrected for sediment delays by Savino et al., show a difference of $.46 \mathrm{~s}$ between station sup (near the western margin of the valley) and station OBB (on the central axis). Assuming velocities of $6.1 \mathrm{~km} / \mathrm{s}$ and $8.0 \mathrm{~km} / \mathrm{s}$ for the lower crust and upper mantle, respectively, there would be a slowness contrast of $.039 \mathrm{~s} / \mathrm{km}$ at the base of the crust. Thus a crustal thickness variation of $12 \mathrm{~km}$ would be required to explain the apparent early arrivals at OBB. However, the residual between the observed teleseismic delay, and the estimated crustal contribution from node1 $\mathrm{C}$, is $.09 \mathrm{~s}$ for SUP and $-.03 \mathrm{~s}$ for $\mathrm{OBB}$. The interstation difference is only $.12 \mathrm{~s}$, which would require crustal thinning of only $3 \mathrm{~km}$. We conclude that the crustal delay predicted by model C (column 4 in Table 3) Is a more reasonable station correction for studying upper mantle effects than is the correction applied by Savino et al. (column 2 of Table 3 ). When this correction is made, the arrival time contrast across the valley is only about $0.12 \mathrm{sec}$, which can be explained by crustal thinning of $3 \mathrm{~km}$ beneath the axis of the valley. 


\section{SEISMICITY AND FOCAL MECHANISMS}

Our edited catalog includes 1608 events during the period June 1975 through September 1977, a period of 28 months. Figure 7 shows the location of all earthquakes recorded at four or more stations in the Imperial Valley network, excluding $D$ events, for the period considered. The most striking aspect of the seismicity pattern is the contrast between the east and west sides of the Brawley-Imperial fault. This point had been noted by Hill et al. (1975) using the 1973-74 catalog. An important feature of our catalog, not present in the 1973-74 catalog, is the active sefsmicity at the Laguna Salada fault, the San Jacinto fault, and the Elsinore fault. It is notable that the Sand Hills fault, which is the continuation of the San Andreas fault, is very quiet as in the 1973-74 catalog. Furthermore, the seismicity has little relation to the geothermal fields, except the Salton Sea station and Brawley station, which happen to be situated on active faults. This pattern of seismicity agrees with previous reports, in that seismic slip at the Brawley-Imperial fault line, and at the northwest along the San Jacinto fault, is the main cause of release of tectonic strain.

In our catalog, there are two significant swarms, one between 19-23 June, 1975, and another on 4 November, 1976. About 100 earthquakes occurred In each period compared to about 2 earthquakes per day on average. These two swarms, like the 1973 swarm, occurred at the Brawley-Imperial fault system. Magnitudes are less than 3, and $94 \%$ of the events occurred at depths less than $8 \mathrm{~km}$.

As in the previous studies, we found a small gap in seismicity at $32^{\circ} 14^{\prime} \mathrm{N}, 115^{\circ} 22^{\prime} \mathrm{W}$, about where the Imperial fault crosses the USA-Mexico border. This gap has since been filled by the Imperial Valley earthquake of 1979 (magnitude 6.6). 
10. ANALYSIS OF LEVELING DATA FOR THE IMPERIAL VALLEY

Our purpose in this analysis is to test some hypotheses about the mode of crustal deformation and to define tectonic crustal movements as well as cultural geodetic effects due to fluid extraction in geothermal areas. We used first order leveling data (unadjusted orthometric heights) provided by the National Geodetic Survey (Reese, 1977). The leveling data are for the profiles shown in Figure 8. The East-West profile from Ocotillo to Ogilby was leveled in 1976 and again in 1977. The North-South profile from Calexico to Niland was leveled in 1971, 1974, and 1977.

Tilt rates are plotted as a function of distance for the Ocotillo-ogilby profile in Figure 9. We prefer to deal with tilt rates rather than uplift rates because no arbitrary reference point is required, and because the tilt rates are more nearly in the form of the original observations, so that errors do not accumulate with profile distance. We have averaged the t11t rates over various distances in order to reduce some of the random errors of measurement. The upper diagram shows the results of averaging over $2 \mathrm{~km}$; the data appear very erratic, and the disturbance near the Imperial fault is evident. Tilt rates are generally negative (down to the east) for the western part of the profile, and average near zero in the eastern half of the profile. Standard deviations for the tilt rates, computed according to the standard formula for accumulation of leveling errors, are shown as horizontal lines in Figure 9. The standard formula is $\sigma=3 \sqrt{\mathrm{L}}$ where $\sigma$ is the standard deviation in $\mathrm{mm}$, and $\mathrm{L}$ is the length in $\mathrm{km}$. This is equivalent to $\sigma=\sqrt{\alpha \mathrm{L}}$ where $\alpha=9 \times 10^{-9} \mathrm{~m}$. For tilt rate, the corresponding formula is $\sigma=(\alpha / d)^{\frac{1}{2}} \Delta t^{-1}$ where $\alpha$ is as above, $d$ is the distance over which tilt is averaged, and $\Delta t$ is the time interval between surveys. As we see 
in Figure 9a, the negative tilting on the west side of the profile exceeds the error bars, while the positive tilting to the east does not. Thus, the geodetic data imply subsidence of the entire east side with respect to the west. Alternately, this may indicate uplift of the west side, and may have the same explanation as the "aseismic uplift of Southern California" reported by Castle et al. (1976). We have argued that the apparent aseismic uplift is caused by systematic errors in the data (Jackson et a1., 1980). These errors are revealed in some leveling by a correlation between apparent uplift and topography. Such errors may be tnvolved here, but it is impossibie to test this hypothesis because of the lack of topographic variation. At the bottom of Figure 9 is a schematic cross-section showing the depth of sediments across the profile. There is no obvious correlation between tilt rate and sediment thickness that would suggest differential setting as the cause of the tilting. In fact, the tilt rate is rather continuous across : the boundary between crystalline rocks and sediments at $35 \mathrm{~km}$.

The tilt rate along the north-south profile Calexico-El Centro-Niland shows wild vacillations well outside the nominal error estimates at each averaging interval. Time histories of the relative benchmark elevations nearly all show reversals in the sense of tilting between $1971.9-1974.2$ on the one hand, and $1974.2-1977.2$ on the other. These vacillations could result elther from many unstable benchmarks, or from local subsidence. We would be loathe to draw inferences about tectonic tilting from these data. 


\section{CONCLUSIONS}

While it still appears likely that the crust is abnormally thin in the Imperial valley, the crustal thinning is probably not so extreme as that suggested by Elders et a1. (1972) and Savino et al. (1977). Comparison of our results with the earlier studies suggest that some of the apparent crustal thinning may result from over-correcting the gravity data and teleseismic arrival time data for the surficial sediments, and from velocity and density variations in the lower crust.

The suggestion by Elders et al. that the Salton Sea, Brawley and Cerro Prieto geothermal fields overlie short sections of spreading center, offset by transform faults, is not supported by the presently available data. The NW-SE tension implied by this model is not consistent with earthquake focal mechanisms of Hill et al. (1975), nor with the geodetic data of Savage et al. (1979) and Thatcher (1979). Our data show that extreme crustal thinning beneath these fields, as might be expected from the spreading center model, is not required in order to explain the teleseismic data. We prefer the "leaky transform fault" model suggested by Hill et al. (1975).

We find that the zone of relatively thick sediment cover, trending NW-SE from the southern end of the Salton Sea, is characterized by relatively high crustal seismic velocities (see Figure 4). These high velocities do not by themselves explain the early teleseismic arrivals found by Savino et al. we suggest that there is crustal thinning in this area as well.

The known geothermal resource areas fall into two groups. The Salton Sea, Brawley, and East Mesa fields are characterized by relatively pronounced positive gravity anomalies, high crustal velocities, and moderate seismic activity. These fields also lie on major faults that are probably responsible both for the geothermal activity and the geophysical anomalies. The Dunes, Heber, and Glamis fields have relatively minor gravity and selsmic velocity 
anomalles, they have low selsmicity, and they are not associated with currently active major faults. Glamis and Dunes lie on the extension of the Sand Hills fault, which is an apparently dormant branch of the San Andreas system.

There is evidence of tectonic vertical geodetic motion along an $E-W$ profile from Ocotillo to Ogilby, although the apparent motion ould be caused by helght dependent systematic errors. Tilt rates are of the order of $3 \times 10^{-7}$ radians per year, down to the east, and concentrated on the west side of the valley. Tilt rates on the east side of the valley are less than the noise level of the data. If real, the tilting may be a result of uplift of the Peninsular Ranges to the west rather than actual subsidence of the valley floor. 


\section{References}

Aki, K: and W.H.K. Lee, Determination of three dimensional velocity anomalies under a seismic array using first $P$ arrival times from local earthquakes, 1. A homogeneous initial model, J. Geophys. Res., 81, 4381-4399, 1976.

Biehler, S., R.L. Kovach and C.R. Allen, Geophysical framework of northern end of Gulf of California Structural Province, in Marine Geology of the Gulf of California, T.H. Van Andel and G.G. Shor, eds,, Amer. Assoc. Petr. Geol. Mem 3, 126-143, 1964.

Brown, L.D. and J.E. Oliver, Vertical crustal movements from levelling data and their relation to geologic structure in the eastern United States, Rev. Geophys. Space Phys., 14, 13-35, 1976.

Castle, R.O., J.P. Church, M.R. Elliott, Aseismic uplift in southern Callfornia, Science, 192, 251-254, 1976.

Chernov, L., Wave propagation in a random medium, McGraw Hill, New York, 1960. Combs, J. and D. Hadley, Microearthquake Investigation of the Mesa geothermal anomaly, Imperial Valley, California, Geophysics, 42, 17-33, 1977.

Elders, W.A., R.W. Rex, T. Meiday, P.T. Robinson, and S. Blehler, Crustal spreading in Southern California, Science, 178, 15-24, 1972.

Facca, G. and F. Tonani, Theory and technology of a geothermal field, Bull. Volcanol., 27, 143-189, 1964.

Fuis, G., C.E. Johnson, and D.J. Jenkins, Preliminary catalog of earthquakes In northern Imperial Valley, California, July-September 1977, USGS OpenFile Report, 1977.

Gilpin, B., and T-C. Lee, A microearthquake study in the Salton Sea geothermal area, California, Bull. Seismol. Soc. Am., 68, 441-450, 1978.

H111, D.P., P. Mowinckel, and L.G. Peake, Earthquakes, active faults, and geothermal areas in the Imperial Valley; California, Science, 188 , $1306-1308,1975$.

H111, D.P., A model for earthquake swarms, J. Geophys. Res., 82, 1347-1352, 1977. 
Holdahl, S.R., Models for extracting vertical crustal movements from levelling data, 9-th GEOP Conference, 1978.

Jackson, D.D., W.A. Lee, and C.C. Liu, Aseismic uplift in southern California: an alternate interpretation, Science, 210, 534-536, 1980.

Johnson, C.E. and D. Hadley, Tectonic implications of the Brawley swarm, Imperial Valley, California, January-February; Bu11. Seismol. Soc. Am., 66, 1133-1144, 1976.

Lachenbruch, A.H., and J.H. Sass, Thermo-mechanical aspect of the San Andreas fault system, in Proceedings of the Conference on Tectonic problems of the San Andreas Fault System, R.L. Kovach and A. Nur, eds., Stanford University Publications, Geological Sciences, 13, Stanford, California, 1973.

Lee, W.H.K., and J.E. Lahr, HYPO 71 (Revised), U.S.G.S. Open-File Report $75-311,1975$.

McGinnis, L.D., M.G. Wolf, J.J. Kohsmann, and C. Patrick Ervin, Regional free air gravity anomalies and tectonic observations in the United States, J. Geophys. Res., 84, 591-602, 1979.

Reese, S.M., Preliminary results of the 1976-77 Imperial Valley levelling surveys, 1977.

Savage, J.C., W.H. Prescott, M. Lisowski, and N. King, Deformation across the Salton trough, California 1973-1977, J. Geophys. Res., 84, 30693079,19

Savino, J.M., W.L. Rodi, R.C. Goff, T.H. Jordan, J.H. Alexander, and D.G. Lambert, Inversion of combined geophysical data for determination of structure beneath the Imperial Valley geothermal region, ERDA Report E(04-3)-1313, 1977.

Schnapp, M., and G. Fuis, Preliminary catalog of Earthquakes in Northern Imperial Valley, Oct. 1 to Dec. 31, 1976, USGS-Caltech Report, 1977. 
Sharp, R.V., Surface faulting in Imperial Valley during the earthquake swarm of January-February, 1975, Bul1. Se1sm. Soc. Am., 66, 1145-1154, 1976.

Steeples, D.W., and H.M. Iyer, Teleseismic P-wave delays in geothermal exploration,

Thatcher, W., Horizontal crustal deformation from historic geodetic measurements in southern California, J. Geophys. Res., 84, 2351-2370, 1979.

Weaver, C.S., and D.P. Hill, Earthquake swarms and local crustal spreading along major strike-slip faults in California, Pure Appl. Geophys., 117, $51-64,1978$. 
Table 1

No. Station Latitude Longitude Elevation, ft. Delay, sec.

\begin{tabular}{|c|c|c|c|c|c|c|c|}
\hline 1 & CPE & 32 & $52.80 \mathrm{~N}$ & 117 & $6.00 \mathrm{~W}$ & 213 & .05 \\
\hline 2 & GLA & 33 & $3.10 \mathrm{~N}$ & 114 & $49.60 \mathrm{~W}$ & 627 & -.29 \\
\hline 3 & IKP & 32 & $38.93 \mathrm{~N}$ & 116 & $6.48 \mathrm{~W}$ & 957 & -.34 \\
\hline 4 & PLM & 33 & $21.20 \mathrm{~N}$ & 116 & $51.70 \mathrm{~W}$ & 1692 & .09 \\
\hline 5 & TPC & 34 & $6.35 \mathrm{~N}$ & 116 & $2.92 \mathrm{~W}$ & 720 & .16 \\
\hline 6 & AMS & 33 & $8.48 \mathrm{~N}$ & 115 & $15.25 \mathrm{~W}$ & 146 & -.40 \\
\hline 7 & BON & 32 & $41.78 \mathrm{~N}$ & 115 & $16.11 \mathrm{~W}$ & 14 & .58 \\
\hline 8 & CRR & 32 & $53.18 \mathrm{~N}$ & 115 & $58.10 \mathrm{~W}$ & 82 & -.32 \\
\hline 9 & $\mathrm{COA}$ & 32 & $51.01 \mathrm{~N}$ & 115 & $7.36 \mathrm{~W}$ & 35 & .15 \\
\hline 10 & COK & 32 & $50.95 \mathrm{~N}$ & 115 & $43.61 \mathrm{~W}$ & -15 & .30 \\
\hline 11 & ING & 32 & $59.30 \mathrm{~N}$ & 115 & $18.61 \mathrm{~W}$ & 2 & .36 \\
\hline 12 & OBB & 33 & $10.04 \mathrm{~N}$ & 115 & $38.20 \mathrm{~W}$ & -61 & .14 \\
\hline 13 & PLT & 32 & $43.87 \mathrm{~N}$ & 114 & $43.76 \mathrm{~W}$ & 61 & -.69 \\
\hline 14 & RUN & 32 & $58.33 \mathrm{~N}$ & 114 & $58.63 W$ & 151 & -.31 \\
\hline 15 & SGL & 32 & $38.95 \mathrm{~N}$ & 115 & $43.52 \mathrm{~W}$ & 104 & -.31 \\
\hline 16 & SLU & 32 & $30.10 \mathrm{~N}$ & 114 & $46.64 W$ & 41 & .09 \\
\hline 17 & SNR & 32 & $51.71 \mathrm{~N}$ & 115 & $26.21 \mathrm{~W}$ & -29 & .56 \\
\hline 18 & SUP & 32 & $57.31 \mathrm{~N}$ & 115 & $49.43 W$ & 221 & -.33 \\
\hline 19 & WLK & 33 & $3.08 \mathrm{~N}$ & 115 & $29.44 \mathrm{~N}$ & -44 & .59 \\
\hline 20 & BSC & 32 & $43.49 \mathrm{~N}$ & 115 & $2.64 \mathrm{~W}$ & 43 & .37 \\
\hline 21 & ELR & 33 & $5.28 \mathrm{~N}$ & 115 & $49.95 W$ & -63 & .25 \\
\hline 22 & NWR & 33 & $6.10 \mathrm{~N}$ & 115 & $41.01 \mathrm{~N}$ & -69 & .19 \\
\hline 23 & WIS & 33 & $16.56 \mathrm{~N}$ & 115 & $35.58 \mathrm{~W}$ & -68 & -.08 \\
\hline 24 & WML & 33 & $0.91 \mathrm{~N}$ & 115 & $37.35 \mathrm{~W}$ & -44 & .42 \\
\hline 25 & CLI & 33 & $8.45 \mathrm{~N}$ & 115 & $31.64 \mathrm{~N}$ & -59 & .46 \\
\hline 26 & FNK & 33 & $22.98 \mathrm{~N}$ & 115 & $38.26 \mathrm{~W}$ & 12 & -.40 \\
\hline 27 & $\mathrm{COY}$ & 33 & $21.84 \mathrm{~N}$ & 116 & $18.63 \mathrm{~W}$ & 210 & -.85 \\
\hline 28 & HOT & 33 & $18.84 \mathrm{~N}$ & 116 & $34.89 W$ & 1975 & -.48 \\
\hline 29 & SMO & 33 & $32.15 \mathrm{~N}$ & 116 & $27.70 \mathrm{~W}$ & 0 & -.51 \\
\hline 30 & INS & 33 & $56.14 \mathrm{~N}$ & 116 & $11.66 \mathrm{~W}$ & 1700 & -.21 \\
\hline 31 & LTC & 33 & $29.34 \mathrm{~N}$ & 115 & $4.20 \mathrm{~W}$ & 458 &.- .28 \\
\hline 32 & PNM & 33 & $58.64 N$ & 115 & $48.05 \mathrm{~W}$ & 1147 & .05 \\
\hline 33 & SHH & 34 & $11.26 \mathrm{~N}$ & 115 & $39.27 \mathrm{~W}$ & 1122 & .46 \\
\hline 34 & WWR & 33 & $59.51 \mathrm{~N}$ & 116 & $39.36 \mathrm{~W}$ & 702 & .29 \\
\hline 35 & $\mathrm{BC} 2$ & 33 & $39.42 \mathrm{~N}$ & 115 & $27.67 \mathrm{~W}$ & 1185 & -.27 \\
\hline 36 & $\mathrm{CO} 2$ & 33 & $50.83 \mathrm{~N}$ & 115 & $20.68 \mathrm{~W}$ & 276 & -.20 \\
\hline 37 & LTM & 33 & $54.90 \mathrm{~N}$ & 114 & $55.10 \mathrm{~W}$ & 744 & .49 \\
\hline 38 & HSP & 32 & $44.81 \mathrm{~N}$ & 115 & $33.71 \mathrm{~W}$ & -6 & .62 \\
\hline 39 & DAH & 32 & $44.07 N$ & 115 & $33.47 \mathrm{~W}$ & -6 & .68 \\
\hline 40 & FTM & 32 & $33.29 \mathrm{~N}$ & 114 & $20.01 \mathrm{~W}$ & 263 & -.55 \\
\hline 41 & KEE & 33 & $38.30 \mathrm{~N}$ & 116 & $39.19 \mathrm{~W}$ & 1366 & -.24 \\
\hline 42 & $\mathrm{KBY}$ & 33 & $2.41 \mathrm{~N}$ & 115 & $42.06 \mathrm{~W}$ & -51 & .42 \\
\hline 43 & PIC & 32 & $54.85 \mathrm{~N}$ & 114 & $38.59 \mathrm{~W}$ & 263 & -.31 \\
\hline 44 & RSE & 32 & $55.53 \mathrm{~N}$ & 115 & $29.95 \mathrm{~W}$ & -41 & .53 \\
\hline 45 & YMD & 32 & $33.28 \mathrm{~N}$ & 114 & $32.68 \mathrm{~W}$ & 76 & -.36 \\
\hline 46 & VGR & 33 & $50.25 \mathrm{~N}$ & 116 & $48.53 \mathrm{~W}$ & 1500 & .37 \\
\hline 47 & $\mathrm{CCM}$ & 33 & $25.75 \mathrm{~N}$ & 115 & $27.88 \mathrm{~W}$ & 488 & -.51 \\
\hline 48 & CPM & 34 & $9.24 \mathrm{~N}$ & 116 & $11.80 \mathrm{~W}$ & 937 & .37 \\
\hline 49 & $\cot$ & 33 & $18.29 \mathrm{~N}$ & 115 & $21.20 \mathrm{~W}$ & 293 & -.21 \\
\hline 50 & LGA & 32 & $45.58 \mathrm{~N}$ & 114 & $29.57 \mathrm{~W}$ & 68 & -.37 \\
\hline
\end{tabular}




\section{TABLE 2}

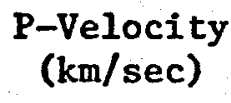

2.0

2.6

3.6

4.7

$6.1 *$

8.0
Depth at Top of Layer

0.0

1.0

2.0

3.0

6.0

20.0 
Table 3

Teleseisnic (.).

\begin{tabular}{|c|c|c|c|c|c|c|}
\hline tion & $\begin{array}{c}\text { Observed } \\
\text { delay }\end{array}$ & $\begin{array}{c}\text { Station } \\
\text { delay }\end{array}$ & $\begin{array}{c}\text { Residual } \\
\text { delay }\end{array}$ & $\begin{array}{l}\text { Estimated } \\
\text { Crustal } \\
\text { delay (1) }\end{array}$ & $\begin{array}{c}\text { Station } \\
\text { delay }\end{array}$ & $\begin{array}{l}\text { Estimated } \\
\text { Residual } \\
\text { delay (2) }\end{array}$ \\
\hline SUP & -.38 & -.61 & .23 & -.47 & -.56 & $.09^{\circ}$ \\
\hline OBB & -.09 & .14 & -.23 & -.06 & -.11 & .05 \\
\hline WLK & .30 & .16 & .14 & .33 & .34 & -.01 \\
\hline ING & .02 & .08 & -.06 & .09 & .11 & -.02 \\
\hline COK & .06 & .17 & -.11 & .02 & .05 & -.03 \\
\hline SNR & .25 & .17 & .08 & .37 & .31 & .06 \\
\hline $\mathrm{COA}$ & -.03 & .01 & -.04 & -.09 & -.07 & -.02 \\
\hline SGL & -.42 & -.31 & -.11 & -.55 & -.56 & .01 \\
\hline BON & 30 & .17 & .13 & .37 & .36 & .01 \\
\hline $\mathrm{BCK}$ & .03 & .09 & -.06 & .09 & .09 & $.00 *$ \\
\hline COT & -.48 & -.51 & .03 & -.36 & -.46 & .10 \\
\hline AMS & -.33 & -.49 & .16 & -.52 & -.66 & .14 \\
\hline RUN & -.22 & -.30 & .08 & -.65 & -.56 & -.09 \\
\hline CRR & -.25 & -.41 & .16 & -.52 & -.57 & .05 \\
\hline PLT & -.30 & -.45 & .15 & $-.94 *$ & -.94 & $.00 *$ \\
\hline SLU & .21 & -.09 & .30 & $-.16 *$ & -.16 & $.00 *$ \\
\hline
\end{tabular}

Loca1

\section{Notes}

(1) defined to be the sum of the station delay (column 5) plus the estimated residual delay (column 6 )

(2) defined to be $h \cdot s-\overline{h \cdot s}$, where $h=14 \mathrm{~km}$ is the assumed thickness of crystalline crust, s is the regional slowness beneath the station, and $h \cdot s$ is the average of h.s over the 10 stations SUP to BCK.

* Regional slownesses were not estimated for the regions containing stations BCK, PLT, and SLU because they were not traversed by enough ray paths. Values here assume "average" crystalline crust. 


\section{Figure Captions}

Figure 1 - Map of Imperial Valley showing major faults, seismic stations used in this work, and known geothermal resource areas (KGRAs). Abbreviations

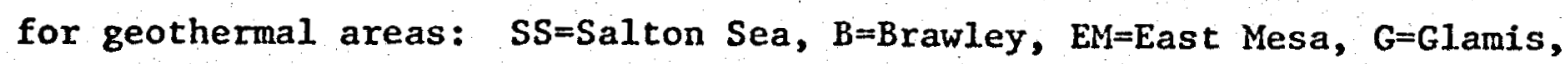
$\mathrm{D}=$ Dunes, and $\mathrm{H}=\mathrm{Heber}$.

Figure 2 - Computer drawn contours of estimated station delays. "Slow" Implies posttive station delays, which correspond closely to regions of thick sedimentary cover.

Figure 3 - Contours of estimated $P$ velocity for the lower crust, assuming all station corrections are zero.

Figure 4 - Contours of estimated $P$ velocity for the lower crust, assuming station corrections estimated from data. Station corrections are given in Table 1.

Figure 5 - Comparison of teleseismic results with station delays estimated from local earthquakes. Circles represent stations within the valley. Crosses represent stations on the margin of the valley, that were not used In the analysis. Top: Assumed teleseismic station delay vs. delay estimated from local earthquakes. The agreement is not good; the rms difference for Interior stations is $.16 \mathrm{~s}$. Bottom: Observed teleseismic delay with no correction for sediments, vs. estimated station delay. Agreement is much better ( $\mathrm{rms}=.09 \mathrm{~s}$ ). Observed teleseismic delays are largely explained by the effects of near surface sediments. 
Figure 6 - Comparison of teleseismic results with predicted crustal delay for vertical $P$ waves using our model $C$. Top: Assumed station delay based on results of Biehler et al. (1964). Agreement is poor (The runs residual for 10 interior stations is $.17 \mathrm{~s}$ ). Bottom: Observed teleseismic delay with no correction. Agreement is good ( $\mathrm{rms}=.08 \mathrm{~s}$ ) indicating that teleseismic observations may be very well explained by crustal delays only.

Figure 7 - Map showing locations of events used in this study.

Figure 8 - Map showing locations of leveling lines.

Figure 9 - Averaged tilt rate vs. profile distance on profile from Ocotillo to Ogilby. Positive values indicate East-up tilting. (a) Averaging window $2 \mathrm{~km}$, (b) Averaging window $5 \mathrm{~km}$, (c) Averaging window $10 \mathrm{~km}$, (d) Averaging window $20 \mathrm{~km}$, (e) Cross section showing sediment thickness vs. profile distance. 


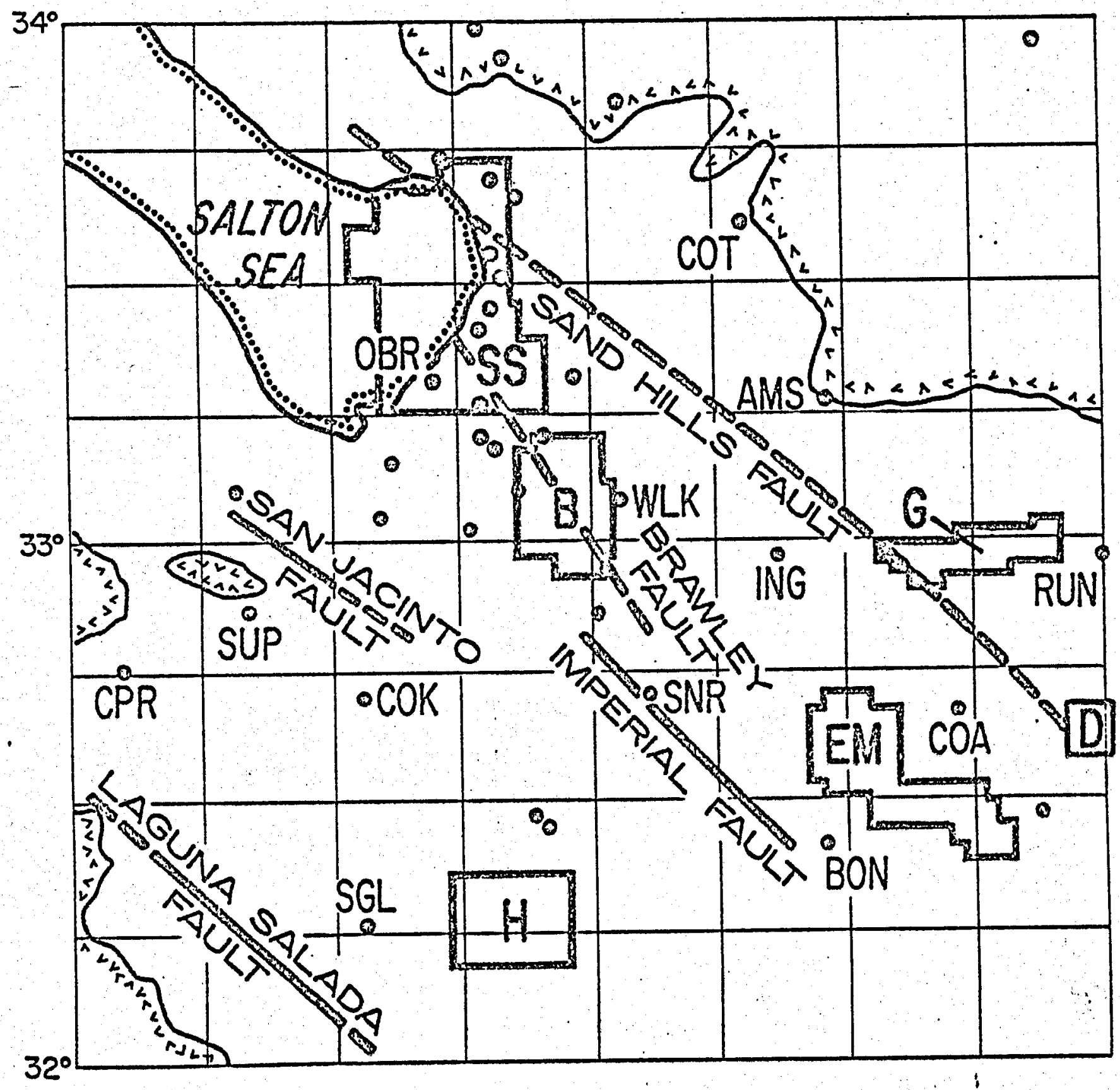




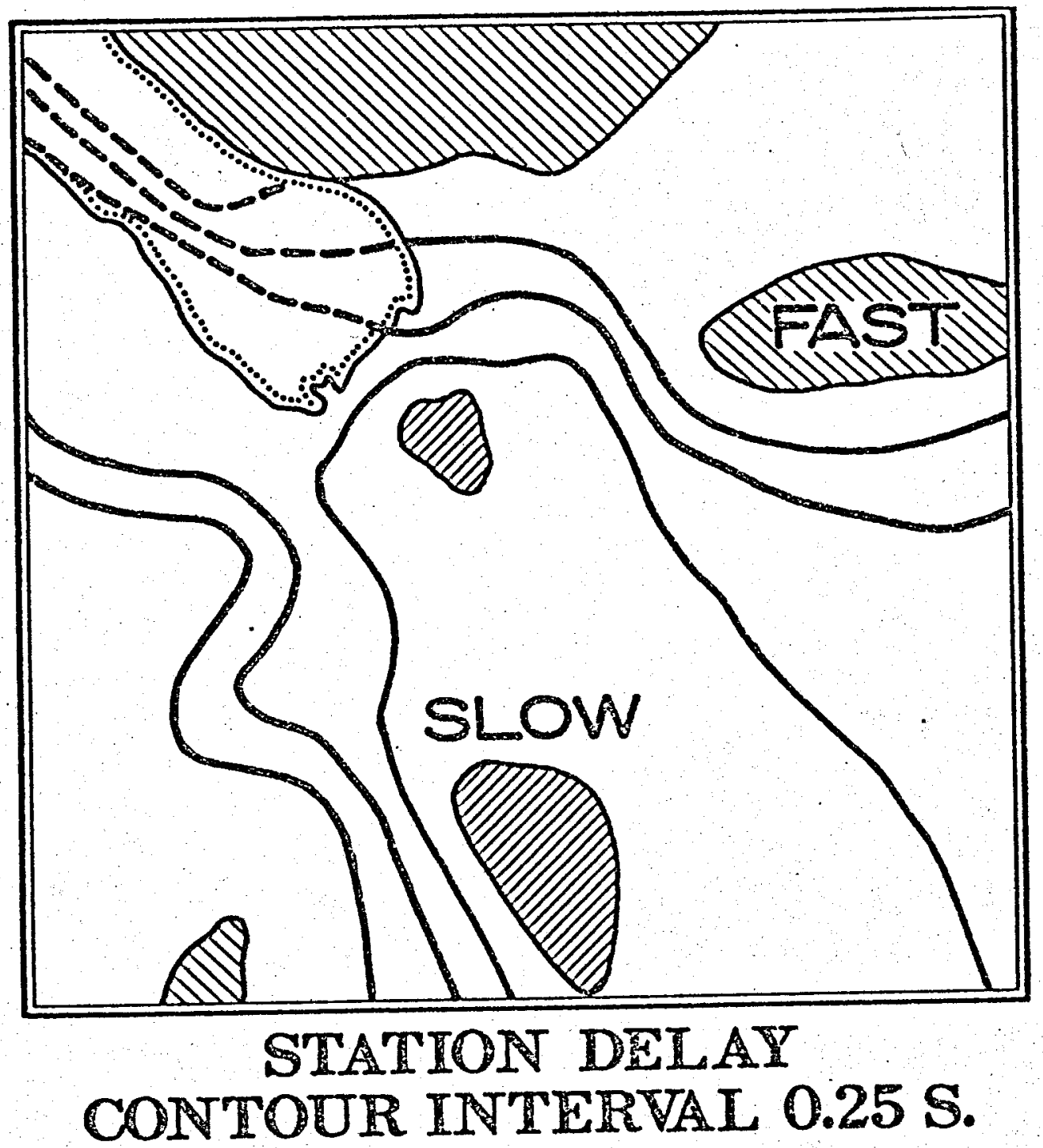

Figure 2 


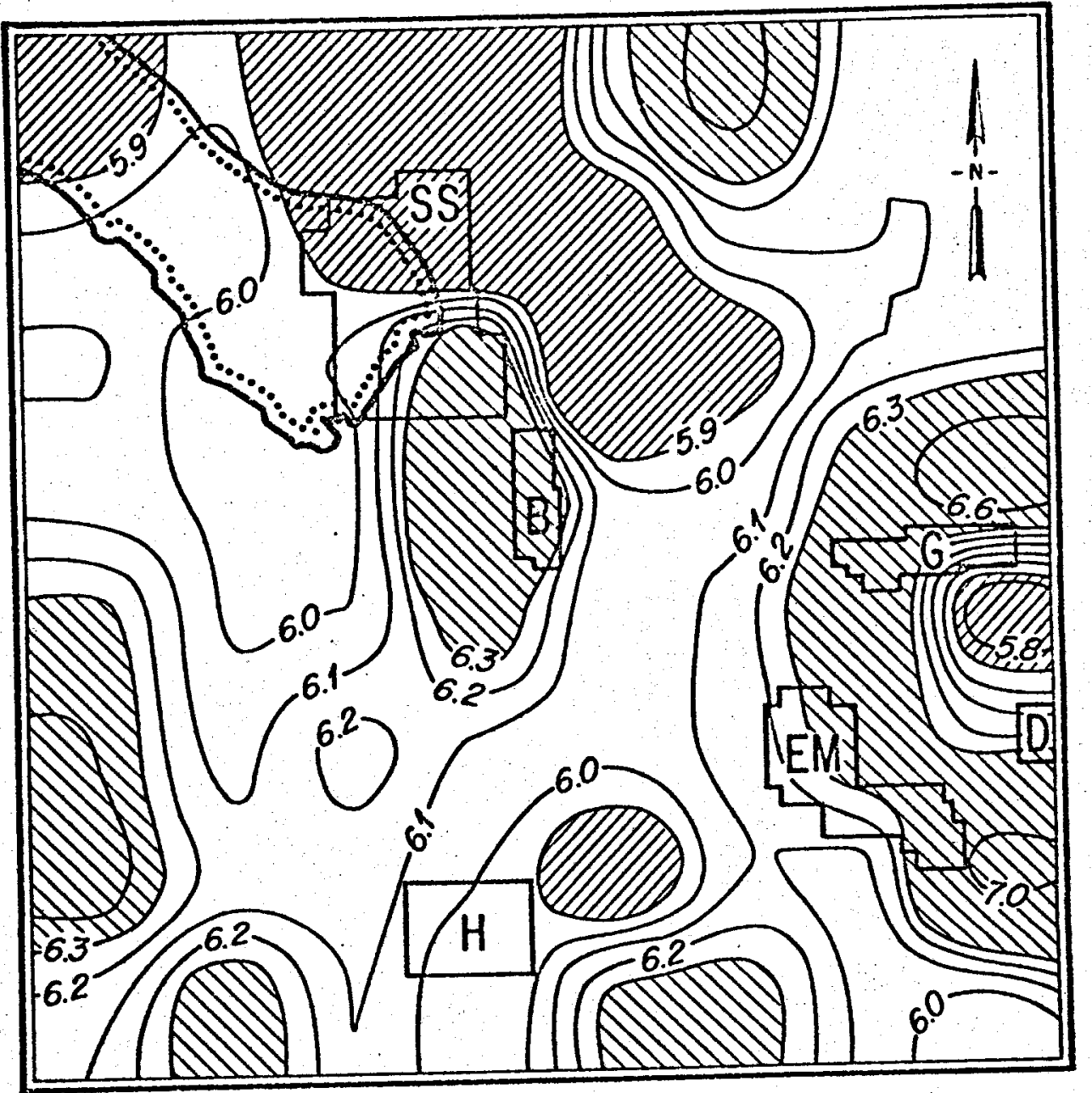

Fighre 3 


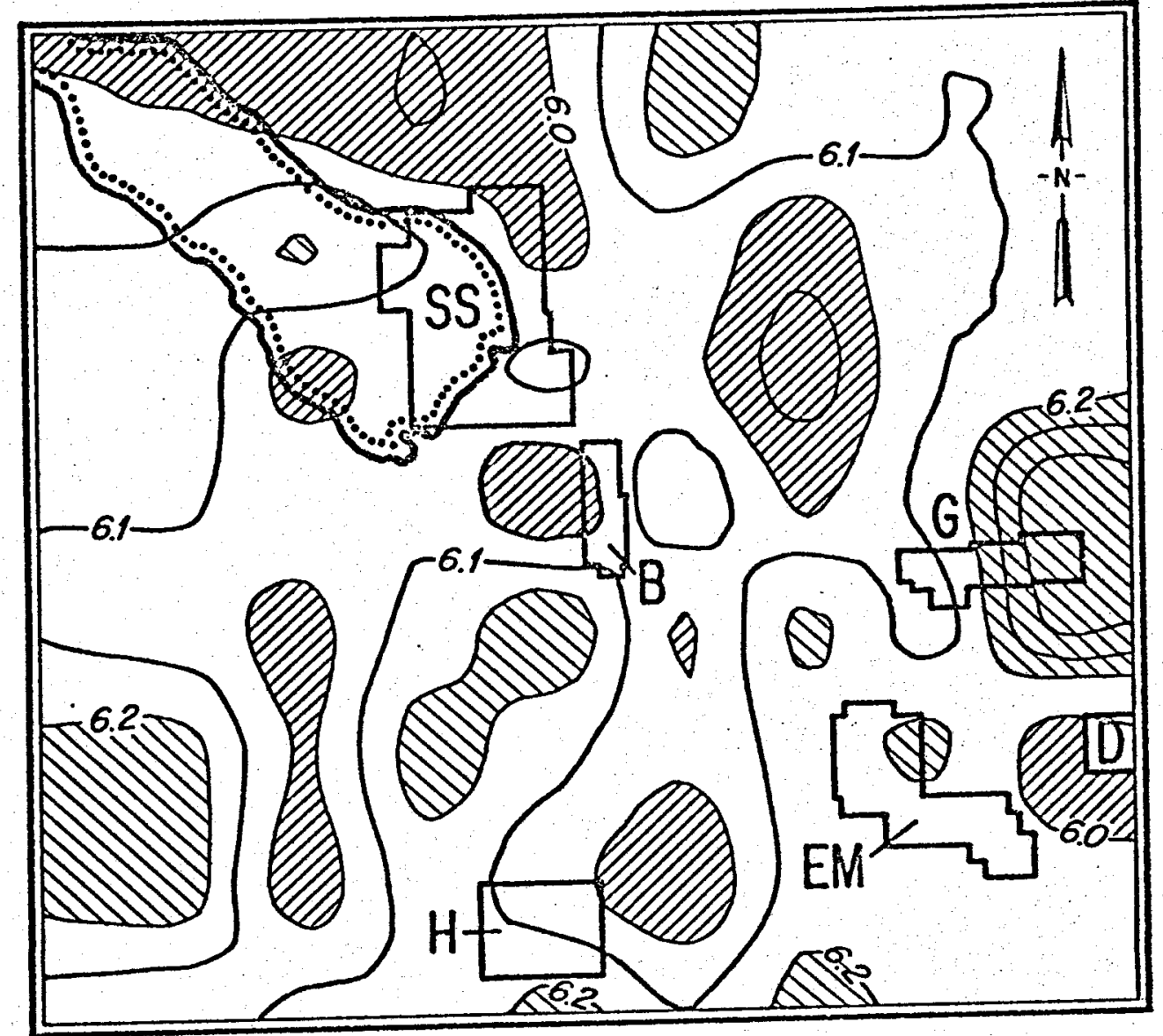

Figure 4 


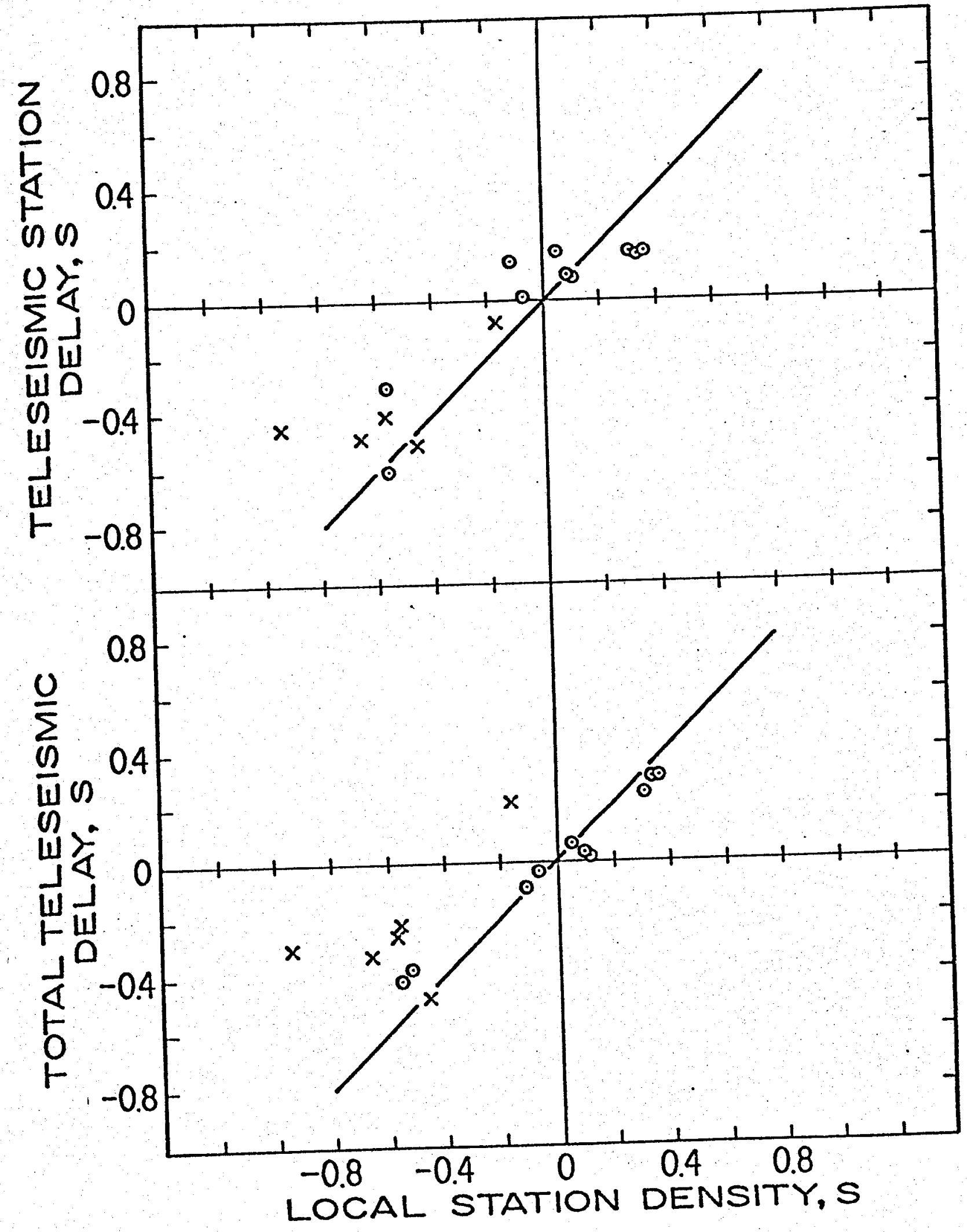

Figure 5 


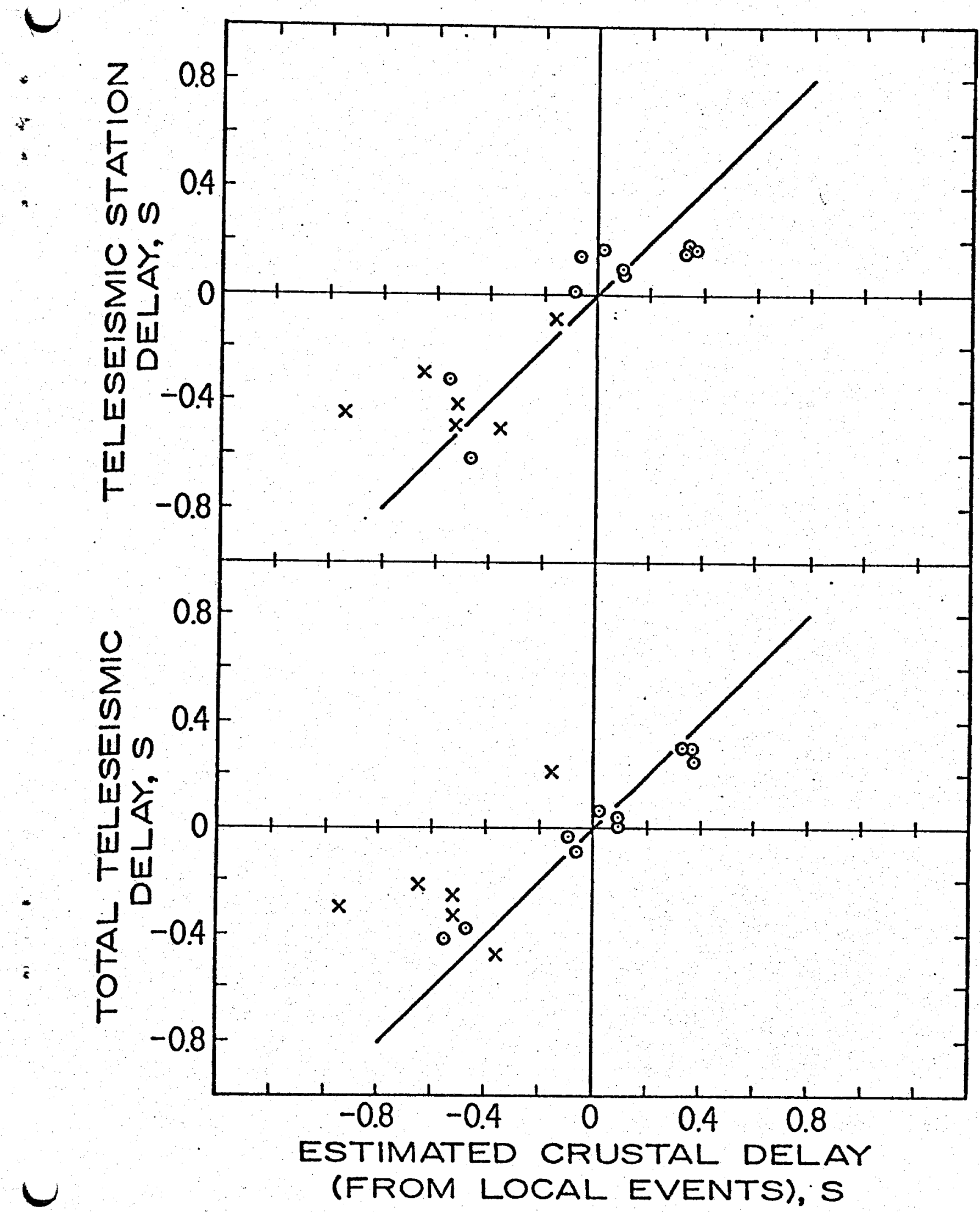

Figure 6 


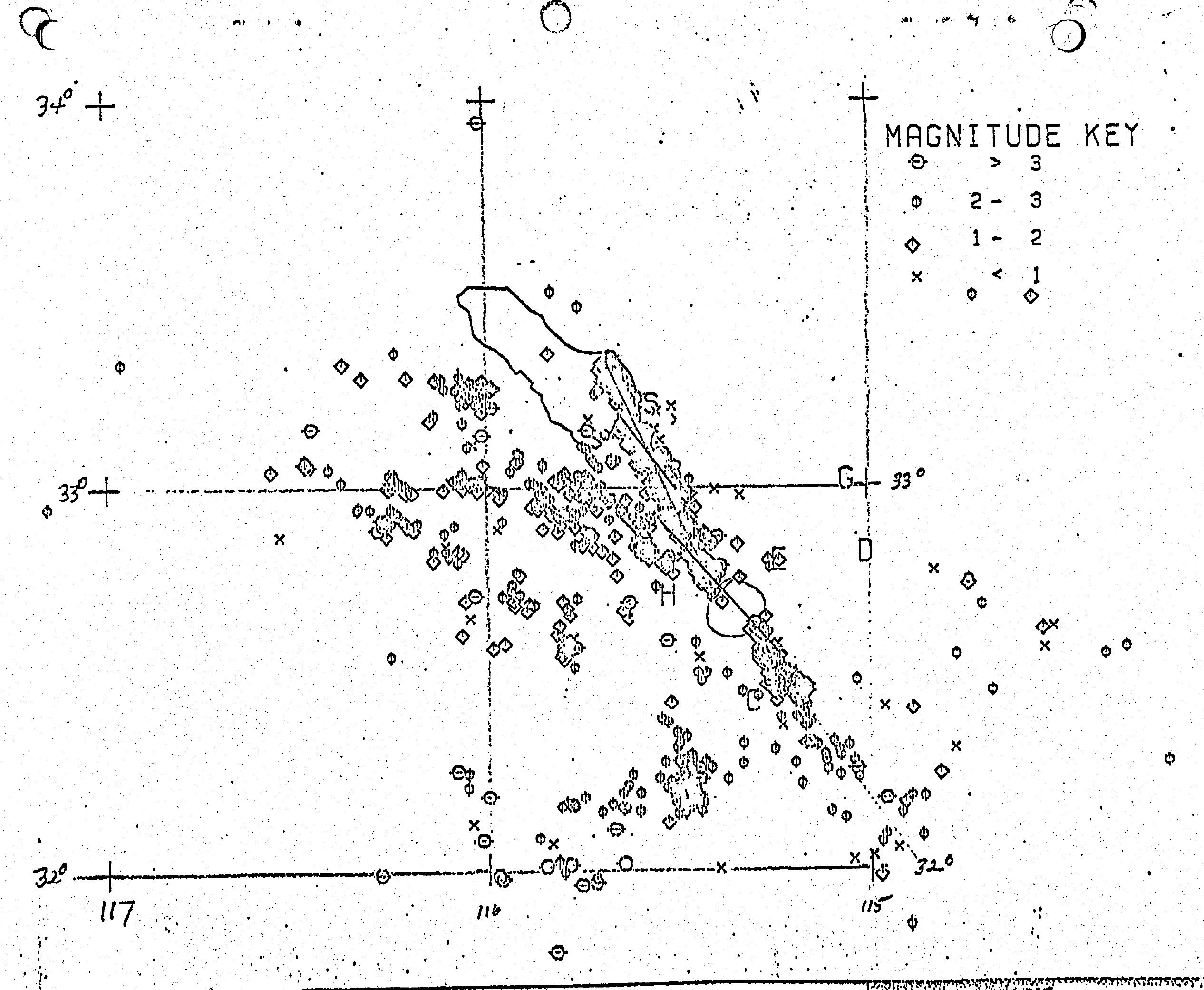




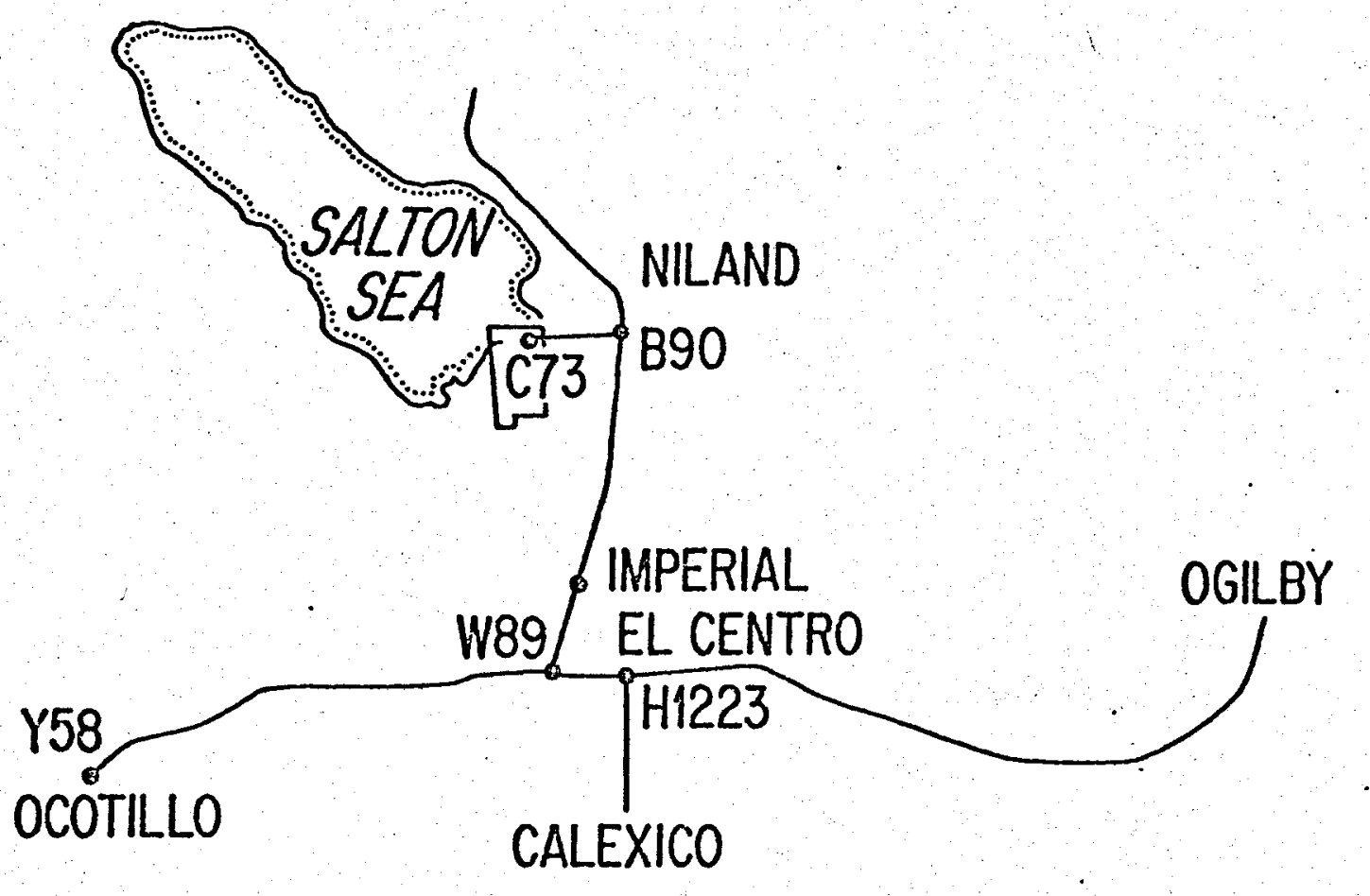

Map showing routes of leveling surveys. 
(1)

(d) $\begin{array}{llllllll}20 & 40 & 60 & 80 & 100 & 120 & 140(\mathrm{~km})\end{array}$

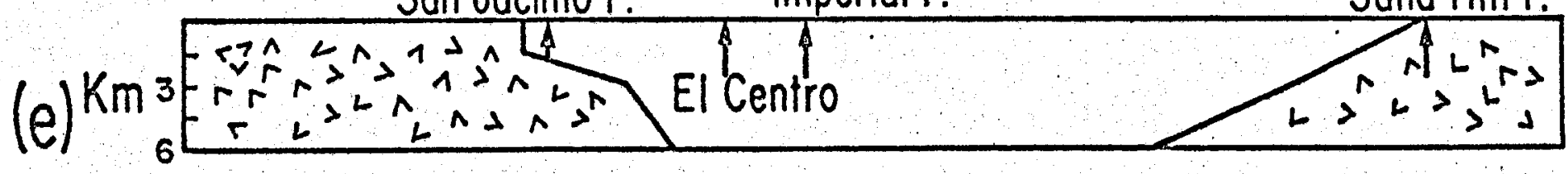

